\title{
aniki
}

Revista Portuguesa da Imagem em Movimento

Portuguese Journal of the Moving Image

\section{D’O Guarani de José de Alencar e Carlos Gomes aos Guaranis do clown Benjamin: Diálogos entre literatura, cinema, circo e música ${ }^{1}$ \\ Danielle Crepaldi Carvalho ${ }^{2}$}

\section{Introdução}

Um dos grandes sucessos teatrais do ano de 1908 é Os Guaranis, "pantomima histórica" encenada no Circo Spinelli pelo popular artista Benjamin de Oliveira. Baseada em duas versões de $O$ Guarani $^{3}$, ambas obras símbolos do patriotismo brasileiro - a original, o romance histórico escrito por José de Alencar (em 1857), e a sua adaptação operística (de 1870), de autoria do compositor brasileiro radicado na Itália Carlos Gomes -, Os Guaranis tinha como peculiaridade ser encenado e protagonizado por um clown negro, intérprete do índio Peri. A carreira bem sucedida da peça pelos Estados de São Paulo e do Rio de Janeiro, em cujos palcos circulou desde 1902, culmina em sua migração do picadeiro à tela do cinema, no filme homônimo exibido, a partir de setembro de 1908, no carioca Cinema-Palace, acompanhado por uma "orquestra aumentada" especialmente para a ocasião ("Cinema-Palace" 1908a, 6).

Este artigo considera que, para a compreensão dos usos dos sons no cinema silencioso, é fundamental o desbastamento do emaranhado da teia social no interior da qual o cinema era engendrado. Procura, portanto, refletir sobre os sentidos construídos pela adaptação de Benjamin de Oliveira, ao palco do circo-teatro e, enfim, ao cinema, colocando-se em primeiro plano os deslocamentos operados pela produção cultural em tempos de primeiro cinema. Para isso,

\footnotetext{
${ }^{1}$ Agradeço as leituras cuidadosas de Eduardo Morettin e dos pareceristas deste periódico, fundamentais ao melhoramento do texto, bem como a Carlos Roberto de Souza, cujos conhecimentos no campo da história do cinema muito colaboraram para o estabelecimento da metragem da fita Os Guaranis, e, enfim, a Fernando Neves, que conhece de berço a história do circo-teatro no Brasil, pelas longas e ricas conversas a respeito do tema.

${ }^{2}$ Universidade de São Paulo, Escola de Comunicações e Artes, 05508-020, São Paulo, Brasil. Pós-Doutoranda da Escola de Comunicações e Artes da Universidade de São Paulo, bolsista FAPESP (15/06383-4).

${ }^{3}$ Optei por atualizar a ortografia das citações, dos nomes próprios, bem como dos títulos de livros e de filmes.

${ }^{4}$ Não pude aferir o número costumeiro de integrantes da orquestra do CinemaPalace. No entanto, a referência ao seu incremento quando da exibição de Os Guaranis é por si só digna de nota.
} 
retrilhará o percurso da criação de José de Alencar, do livro impresso às cenas operística, teatral, circense e, enfim, cinematográfica - ponderando, no que tange à música, no papel desempenhado pela partitura de Carlos Gomes em cenas tão díspares. O objetivo aqui é compreender o cinema da aurora do século XX no interior do cadinho cultural de seu tempo e, daí, a relação de mão-dupla que tal arte estabelecia com o âmbito dramático e o musical, e a presença, na sala do cinema, da polifonia social/ sonora. Dada a ausência empírica da matéria fílmica, o percurso se tecerá a partir dos registros escritos e visuais que restaram da obra (anúncios, artigos, crônicas, fotografias), espalhados por arquivos brasileiros como o Centro de Documentação e Informação da Fundação Nacional das Artes (CEDOC-FUNARTE), O Arquivo Nacional e a Hemeroteca Digital Brasileira (que disponibiliza a íntegra dos principais periódicos publicados à época).

O plural ao qual se refere o título da obra de Benjamin de Oliveira - Os Guaranis - relê, pela chave crítica, a personagem-título concebida por José de Alencar e Carlos Gomes. Protagonista da pantomima e do filme, o clown negro Benjamin - artista multifacetado, exímio mímico, humorista, instrumentista e cantor - inverte os sinais que historicamente silenciaram o papel das etnias africanas na conformação da identidade brasileira, elevando-as simbolicamente ao papel de protagonismo, ao inserirem-nas no cerne das cenas circense e cinematográfica do Rio de Janeiro, crescentemente frequentadas pelas elites sociais. Artista que usualmente utilizava a máscara branca - a máscara primordial do pagliaccio da commedia del arte, segundo Dario Fo, donde mais tarde se originará o Pierrot (apud. Silva 2007, 44) - abandona-a em Os Guaranis, surgindo no picadeiro num só tempo negro e índio, interpretação derrisória que merece o plural que dá título à peça.

A denominação Os Guaranis acena, ademais, para a mescla entre a cultura erudita e a popular que caracterizava a sociedade brasileira da época - mescla que o âmbito circense tão bem explicita, já que historicamente se apropria, com a disruptiva sem-cerimônia que lhe é típica, dos repertórios dramático e musical eruditos, inserindo-o no centro do picadeiro, adequado às características individuais da trupe e às dimensões mais exíguas do palco e da banda circense. Na sala do Cinema-Palace, aquela "orquestra aumentada" especialmente para o programa do qual fazia parte a fita ("CinemaPalace" 1908a, 6. Cf. Imagem 1) provavelmente mimetizava a encenação circense da obra de Benjamin, fazendo com que a música grandiloquente de Gomes conduzisse as sombras cinzentas a desempenharem a milenar arte da pantomima, que o cinema soube tão bem eternizar. $\mathrm{O}$ anúncio que convida o público a prestigiar a fita denomina-a "farsa", arrematado ato derrisório, já que arrastava a obrafonte àquele que a hierarquia clássica considerava o rés-do-chão dos 
gêneros artísticos, transformando em baixa comédia um drama de fundação da identidade nacional.

\section{Os Guaranis do clown Benjamin de Oliveira}

Em 23 de fevereiro de 1907, uma das Fagulhas do cronista A. A. tecia comentários entusiásticos ao espetáculo ocorrido dois dias antes no Circo-Teatro Spinelli, comemorativo ao centenário de apresentações da companhia naquele sítio que ficava no Boulevard de São Cristóvão, entre o Mangue e o matadouro, no Rio de Janeiro:

Quereis ver o povo na sua manifestação mais pitoresca, quereis apanhá-lo em flagrante? Não o procureis nas avenidas da moda, nem nos teatros, nem mesmo no Passeio Público: ide ao circo Spinelli.

Mas que público bem-humorado e alegre, e como se vê que ele quer bem a todo o pessoal do circo! Que boas, que sadias gargalhadas! (A. A. 1907,2$)^{5}$

Por detrás da alcunha de A. A. estava Arthur Azevedo, o mais popular teatrólogo de seu tempo, autor de dezenas de comédias, sainetes, operetas, revistas de ano; homem que se bateu durante porção considerável da vida em prol do teatro nacional e da classe teatral, não poucas vezes defendendo publicamente artistas profissionais (que então possuíam fama pouco lisonjeira) da detração de seus colegas cronistas (Mencarelli 1999; Neves 2006). A surpresa explicitada pelo autor, que era dos mais profundos conhecedores do teatro popular, frente à companhia de Spinelli, prova cabalmente o modo enviesado como a crítica olhava o circo, e o lugar por ele ocupado então no interior dos gêneros teatrais. A crônica de Azevedo propõe um deslocamento do olhar de seus leitores, demasiado voltados, então, às vias centrais da cidade, recém-reformadas pelo poder público (sobretudo a Avenida Central e a Avenida Beira-Mar), de acordo com a pompa europeia (Dimas 1883; Souza 2003; Autor 2014), fazendo-os mirar o arrabalde.

O artigo é, até onde se tem notícia, o primeiro a olhar a sério a arte da companhia de Spinelli, bastante apreciada pelo público - daí o número não desprezível de récitas que ela dava por onde passava mas ainda desprezada pela "elite" social do período, da qual o cronista cobra atenção. ${ }^{6}$ Mais que isso, o texto é documento precioso de

\footnotetext{
${ }^{5}$ Devo a localização da crônica a Lucinéia A. dos Santos $(2015,139)$ e a Erminia Silva (2007, 230-231).

${ }^{6}$ Cabe aqui uma referência ao ótimo trabalho de Sílvia Souza, sobre o âmbito teatral carioca dos anos de 1832 a 1868, no qual a autora defende a heterogeneidade do público que, então, frequentava os circos. Todavia, a passagem do tempo não parece ter incorrido no incremento desta frequentação pela elite social carioca, ou das referências a ele por parte dos cronistas do período - por
} 
guarda da história do Spinelli e, mais especificamente, dos meus objetos de estudo neste artigo: o clown Benjamin de Oliveira e a "aparatosa pantomima de costumes indígenas" (Circo Spinelli 1906a) Os Guaranis, também denominada então "original e grande pantomima de costumes nacionais." ("Circo Spinelli" 1904, 8) ou "farsa" (Circo Spinelli 1906d, 2) - os limites escorregadios dos gêneros desafiam o analista contemporâneo, especialmente quando - e é este o caso - a obra em questão se perdeu.

Os Guaranis interessa-me, sobretudo, devido à sua posterior migração do picadeiro do circo-teatro de S. Cristóvão à tela do central Cinema-Palace, em fita rodada por Antonio Leal, da Photocinematografia Brasileira, e exibida, como ocorria à maioria da produção cinematográfica da época, em meio a um conjunto de fitas curtas. Neste caso específico, Os Guaranis em sua estreia fechou um programa de quatro títulos nacionais, rodados pela companhia em questão, 1- "Os capadócios da Cidade Nova", 2- "Sô Lotéro e nhá Ofrásia com seus produtos à Exposição" e 3- "Tudo pela higiene". Todas de vieses cômicos, a se apoiarem em gêneros teatrais caros ao público carioca, como a comédia de costumes e a farsa - a segunda fita citada realizava uma fusão de gêneros, unindo a comicidade à faceta documental, já que tinha como pano de fundo a "Exposição Nacional" comemorativa aos cem anos da abertura dos portos, evento que procurava inserir o Rio de Janeiro no calendário dos países civilizados, nos quais as "Exposições Universais" davam o tom da modernidade (Gunning 1994). A contar pela indicação do anúncio, era cômica mesmo a fita Os Guaranis, embora fosse baseada num romance que, pelo seu cunho de narrativa de formação nacional (Candido 1959), investia densamente na dramaticidade. 


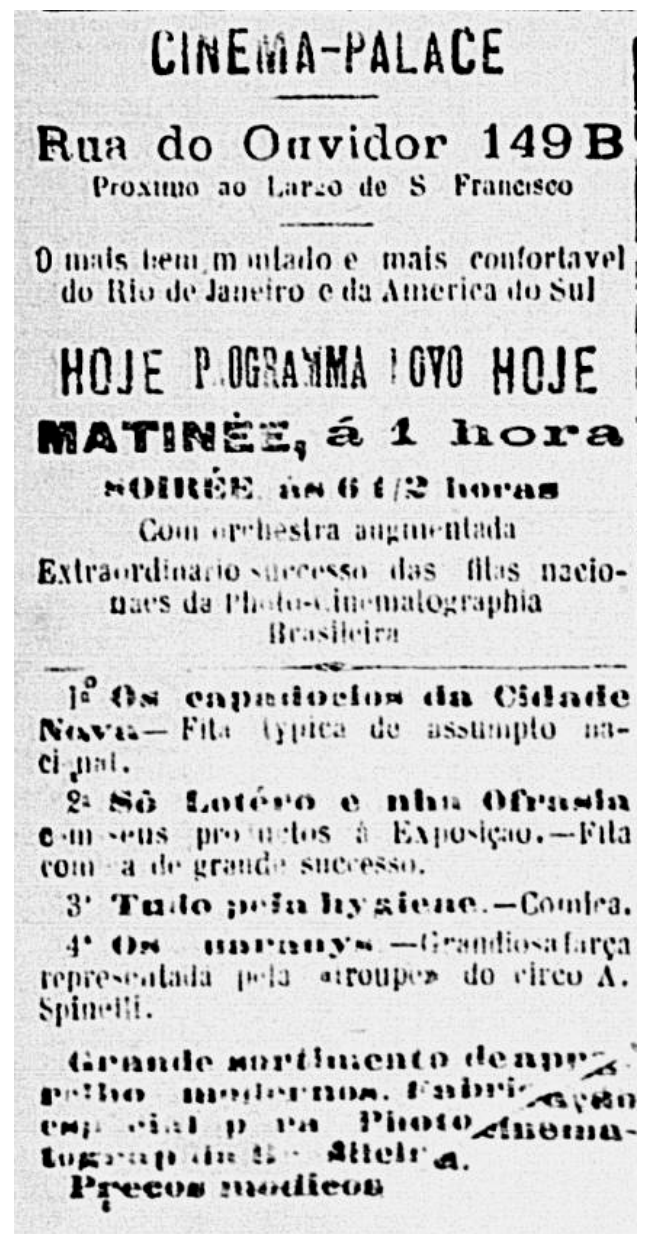

Imagem 1: Anúncio do programa do Cinema-Palace com a estreia de Os Guaranis.

("Cinema-Palace" 1908a, 6) | (c) Hemeroteca Digital Brasileira.

Além de a fita Os Guaranis não ter sobrevivido ao tempo, não restam discursos substanciais a seu respeito, uma vez que as películas da época eram, quando curtas (como é o caso desta, de cerca de 10 minutos de duração), referidas apenas brevemente na imprensa. Portanto, procurarei doravante reconstruir o percurso da pantomima às telas, buscando num só tempo refletir sobre a apropriação do teatro pelo cinema, e sobre os sentidos históricos do gesto do Benjamin de Oliveira. Ora, o título dado à peça - Os Guaranis, no plural (quiçá em alusão à "dinastia de Manoel Pery", nas palavras de Arthur Azevedo no supracitado artigo, a qual trabalhava então no Spinelli) - tomava criticamente a personagem-título de Alencar e Gomes, os quais burilaram um indígena de fortes traços europeus, num esforço de construção de uma identidade nacional que atrelasse o Brasil à civilização do Velho Mundo, pensamento vigente no período. Protagonista da pantomima e do filme, o clown negro Benjamin invertia os sinais que historicamente silenciaram o papel das etnias africanas na formação da identidade brasileira, elevando-as ao papel de protagonismo, ao mesmo tempo em que acenava para a mescla entre a cultura erudita e a popular que caracterizam a sociedade brasileira. 
Esta mescla está muito bem posta pelos contornos da pantomima circense encenada por Benjamin de Oliveira, sobre a qual restam relatos mais extensos - nos quais me deterei, no intuito de preencher a lacuna deixada pela ausência da película. Relata a biógrafa de Benjamin, Ermínia Silva, que a pantomima estreou em São Paulo em 1902, como uma explícita adaptação ao picadeiro da obra de Alencar, com o título de D. Antônio e os Guaranis (Episódio da História do Brasil), obra de autoria Manoel Braga dotada de "22 quadros, 70 pessoas em cena e 22 números de música”, arranjada à banda da companhia pelo maestro João dos Santos (a partir da original de Carlos Gomes) e encenada por Benjamin de Oliveira e Cruzet (Silva 2007, 210) - este último deixa de ser mencionado já em 1903, quando a Companhia apresenta-se no Rio de Janeiro ${ }^{7}$. O registro publicado no Estado de S. Paulo, citado por Ermínia Silva (2007, 210211), é, até onde pude observar, o único que apresenta em detalhes a relação das personagens principais da pantomima. São elas: Ceci (Miss Ignez); Peri (Mr. Benjamin); D. Antonio (Mr. Theophilo); O inglês (Mr. Salinas); O criado (Mr. Vampa); Cacique (Mr. Cruzet) ${ }^{8}$; Mulher do Cacique (Maria da Glória); Guerreiras (Miss Luisa, Miss Candinha, Mlle. Vitória e Mlle. Aveline).

O entrecho da obra de José de Alencar (1857) é, em linhas gerais, o seguinte: D. Antonio de Mariz é um dos nobres portugueses que emigraram ao Brasil nos princípios da colonização (tendo, em meados do século XVI, composto as hostes do governador Mém de Sá em suas incursões contra os invasores franceses e na fundação da cidade do Rio de Janeiro). José de Alencar sublinha, n'O Guarani, os lastros que desejava estabelecer da personagem com a realidade? ${ }^{9}$ No momento em que se passa a história, início do século XVII, D. Antonio habita as matas dos arredores do rio Paquequer, num rincão do Rio de Janeiro, com a mulher, os filhos (além de Cecília/Ceci, D. Diogo de Mariz, que por engano mata uma indígena Aimoré, durante uma caçada, e acaba inadvertidamente sendo responsável pela

\footnotetext{
${ }^{7}$ No ano seguinte, Benjamin de Oliveira era a grande estrela da companhia. Tanto que, por ocasião do deslocamento do Spinelli de Niterói ao Rio de Janeiro, a folha $O$ Fluminense publica uma carta assinada apenas pelo artista, na qual ele agradece os obséquios do público e da imprensa locais, lamentando não poder se despedir pessoalmente de cada um dos amigos, e anuncia sua partida próxima à capital federal, juntamente com a trupe ("Circo Spinelli" 1903, 3).

${ }^{8}$ Cruzet fora, conforme já apontado, co-encenador da montagem primordial da pantomima, juntamente com Benjamin de Oliveira, tendo a sua esposa Ignez Cruzet desempenhado o papel de Ceci. A partir de 1 de fevereiro de 1908, os principais papéis femininos da trupe do Spinelli caberiam a Lili Cardona, que além de atriz era "acrobata, equilibrista, ginasta excêntrica e aramista" - como Benjamin, uma artista completa. (Silva 2007, 242)

9 À descrição de que D. Antônio de Mariz tratava-se de "fidalgo português cota d'armas e um dos fundadores da cidade do Rio de Janeiro", o escritor ajunta a seguinte nota de fim de capítulo: "Este personagem é histórico, assim como os fatos que se referem ao seu passado, antes da época em que começa o romance. Nos Anais do Rio de Janeiro tomo $1^{\circ}$, pág. 328 lê-se uma breve notícia sobre sua vida." (Alencar 1857, I Parte, 11, 171).
} 
débâcle da casa paterna) e um rol de aventureiros que visavam às investidas no sertão. Dentre esses homens está o italiano Loredano, ex-frade carmelita, que abandonara a batina com o sonho de fazer fortuna explorando uma mina de prata cujo mapa lhe caíra em mãos. Para atingir os seus propósitos, Loredano emprega-se no bando de D. Antonio, conhecendo a loura, branca, pura e heráldica $\mathrm{Ceci}^{10}$, por quem se apaixona lascivamente - como o eu-narrativo prodigamente ressalta. Caberá ao índio guarani Peri - que, por sua vez, era "de alta estatura, linha as mãos delicadas; e a perna ágil e nervosa (...), apoiava-se sobre um pé pequeno, mas firme no andar e veloz na corrida”, etc. (Alencar 1857, I Parte, 33) - salvar a mocinha das mãos do aventureiro e do sem-número de perigos que a afrontam, até que, abraçando a fé cristã, ele ganha o direito de retirá-la da casa paterna, já em posse da tribo dos Aimorés. No desfecho, sobram apenas Peri e Ceci, agarrados a uma palmeira arrastada pela torrente, espécie de releitura da fábula bíblica de Noé.

A documentação histórica serve a Alencar de ponto de partida aos voos imaginativos e à exacerbação de um conteúdo programático: a obra inventava a gênese da nação brasileira à maneira do pontuado pelo cientificismo do século XIX e por agremiações como o Instituto Histórico e Geográfico Brasileiro, o IHGB, do qual, conforme aponta Lilia Schwarcz, foram sócios vários escritores românticos, a exemplo de Alencar. Foge ao meu objetivo penetrar profundamente a literatura acerca do IHGB. Cabe ressaltar, em linhas gerais, apoiando-me na obra de Schwarcz $O$ espetáculo das raças, o anseio dos membros da agremiação de "formular uma história ['oficial'] que, a exemplo dos demais modelos europeus, se dedicasse à exaltação e glória da pátria” (Schwarcz 1993, 102), ou então o papel da Independência do Brasil na construção do ideário romântico (Schwarcz 1993, 104) e, ainda assim, o louvor à dinastia portuguesa (tanto que D. Pedro II, considerado "protetor perpétuo" da casa, era seu presidente honorário e doador maiúsculo), bem como o louvor ao regime monárquico e à escravidão:

Concretizado alguns anos após o movimento de Independência, o instituto é de alguma forma filho dileto de um espírito de época que nesse momento se difunde. 'A Independência tem um papel decisivo para o ideal romântico', afirma Antonio Candido ao caracterizar esse período em que a literatura torna-se um recurso de valorização do país, quer reproduzindo o que se fazia na Europa, quer exprimindo uma realidade específica e local. (...) Fazer história

\footnotetext{
10 “D. Cecília (...) era a deusa desse pequeno mundo que ela iluminava com o seu sorriso, e que alegrava com o seu gênio travesso e a sua mimosa faceirice. (...)/ Os seus grandes olhos azuis, meio cerrados, às vezes se abriam languidamente como para se embeberem de luz, e abaixavam de novo as pálpebras rosadas./(...). Sua tez alva e pura como um froco de algodão, tingia-se nas faces de uns longes cor de rosa, que iam, desmaiando, morrer no seu colo de linhas suaves e delicadas. (...) Seus longos cabelos louros, enrolados negligentemente em ricas tranças, descobriam a fronte alva (...).” (Alencar 1857, I Parte, 19, 43-44).
} 
da pátria era antes de tudo um exercício de exaltação. (Schwarcz 1993, 107)

Se o IHGB procurava construir uma história com base no rigor documental, a historiadora igualmente vê emergir dele um esforço seletivo. Do projeto de nação forjado pelo grupo ficariam de fora os negros e os índios, considerados, os primeiros, incivilizáveis; e tomados, os segundos, ora como símbolos da identidade nacional, na esteira da tradição literária ocidental, ora como seres passíveis da "civilização" por meio da catequização e do jugo do trabalho (considerado, nesta visão etnocêntrica, "enobrecedor") (Schwarcz 1993, $111,113)^{11}$. Daí o apagamento do negro da história forjada pelo IHGB e a defesa de um "aperfeiçoamento" racial que tinha como ponto de chegada o elemento branco (Schwarcz 1993, 112). Neste sentido, é simbólica a especificidade do amálgama racial forjado em O Guarani, no qual a união entre Peri e Ceci apenas ocorre uma vez que o índio se dobra à fé cristã. ${ }^{12}$

Ao se observar Os Guaranis do Circo-teatro Spinelli a contrapelo da obra de Alencar, salta aos olhos como a historiografia oficial conviveu com propostas outras de historiografias, atentas à vasta gama de etnias que construíram o Brasil, já que originárias no seio delas. Neste deslocamento do olhar do centro às bordas, é fundamental que se atente à arte oriunda de grupos dedicados a gêneros artísticos de cunho popular, desconsiderados por uma crítica cujos parâmetros de avaliação pautaram-se historicamente pelos pressupostos da arte erudita (Thomasseau 2009). Circos-teatros como o Spinelli são pródigos exemplares disso e fundamentais para que pensemos o primeiro cinema, que tanto bebeu desses gêneros.

Destaque-se que, em comparação à obra de José de Alencar, o elenco da pantomima de Benjamin é bastante reduzido. Elimina-se, por exemplo, a personagem de Isabel, filha adulterina de D. Antonio com uma índia (portanto, meia-irmã de Ceci), que representa no romance o elemento oriundo da miscigenação do colonizador com o povo autóctone, "Era um tipo inteiramente diferente do de Cecília; era o tipo brasileiro em toda a sua graça e formosura, com esse en-

\footnotetext{
${ }^{11}$ Para um resumo desses debates, conferir Morettin 2013.

${ }^{12}$ Embora o cerne deste trabalho não seja a análise cerrada de $O$ Guarani de José de Alencar ou da inclinação política do autor, vale aqui destacar trabalhos mais recentes que colocam em perspectiva os paradigmas teóricos defendidos por estudiosos como Antonio Candido e Alfredo Bosi, que enfatizam a "tendência fitocolonialista" (Oliveira 2005, 137-138) de Alencar. Efetivamente, na exegese nos periódicos contemporâneos a Alencar realizada para a escrita deste artigo, pude recolher a seguinte referência ao autor, alusiva à sua atuação como deputado, que problematiza os pressupostos explicitados numa obra como O Guarani: "O ilustrado Sr. José de Alencar, em 7 de julho, submeteu à câmara o seu projeto n. 121, permitindo ao escravo a formação de um pecúlio destinado à sua manumissão." (s.a. 1871, 4). A sua defesa legal de que os negros tivessem direito a amealhar uma soma em dinheiro destinada à alforria coloca em debate a filiação estrita do autor no que concerne ao esforço de apagamento do elemento africano da história nacional, proposta pelo IHGB.
} 
cantador contraste de languidez, de malícia, e de vivacidade ao mesmo tempo". (Alencar 1857, I Parte, 46). O jovem europeu Álvaro, dileto funcionário de $\mathrm{D}$. Antonio o qual o velho senhor a princípio deseja unir a Ceci, porém que no desfecho se apaixonará por Isabel e perecerá junto dela, tampouco surge na peça. Já o vilão, o italiano Loredano, transforma-se na peça num inglês, com fins provavelmente cômicos - na distribuição dos papéis da montagem primeva da pantomima, publicada por Ermínia, pode-se observar que o elenco tinha preposto aos nomes os títulos de Mr. e Ms., e Arthur Azevedo destaca do seguinte modo a falácia do sotaque daquela trupe, segundo ele, eminentemente brasileira:

Conquanto os palhaços finjam sotaque estrangeiro, o pessoal do circo Spinelli é todo nacional, todo à exceção de um japonês, que tem mais anos do Brasil que do Japão, e é pai de uma cambada de brasileirinhos, todos insignes acrobatas, como o pai. (A. A. 1907, 2).

Do conjunto de personagens, Azevedo destaca, claro, Benjamin de Oliveira, que ele considera, "um saltador admirável, um emérito tocador de violão, um artista que faz da cara o que quer, parecendo ora um europeu louro como as espigas do Egito, ora o índio vermelho apaixonado pela filha de D. Antonio de Mariz;", concluindo pela assertiva de que "ele é o nosso Tabarin" - elogiosa, já que insere o artista brasileiro na mesma tradição de representação à qual pertencera o célebre prestidigitador e cômico dos teatros de feira parisienses do século XVI-XVII ${ }^{13}$. Porém, o teatrólogo igualmente chama atenção para a personagem do criado, funcionário dileto de $\mathrm{D}$. Antonio na obra original, transformado, na adaptação, numa espécie de Sancho Pança: "Um dos Perys, o mais novo, creio, fez-me rir a perder no papel do velho Ayres (...)", diz Azevedo (A. A. 1907, 2). A paródia é característica cara a gêneros teatrais de cunho popular, tendo migrado a circos como o Spinelli, que, a partir de fins do XIX, somavam os números de funambulismo às encenações teatrais, representadas, na segunda parte do espetáculo, entre o palco e o picadeiro.

Outro traço incontornável deste gênero, também comum a outros exemplares do teatro popular (como a ópera-bufa, a opereta e a revista de ano) é a rutura das barreiras entre o erudito e o popular. Os Guaranis era acompanhado por "22 números de lindos trechos de música extraídos da bela partitura - O Guarany, do imortal maestro Carlos Gomes." (“Circo Spinelli” 1906e, 4), segundo anúncio da pantomima. A redução da partitura da ópera aos instrumentos da banda circense soma-se ao investimento na espetacularidade, característica comum aos palcos populares e incontornável ao circo - cuja primazia pertence aos números de destreza física. A pantomima concluía-se numa apoteose denominada "A fuga de Pery com Cecy". Seu prólogo igualmente possuía a dimensão de tableau

\footnotetext{
${ }^{13}$ Para um compêndio de sua obra publicado à sua época, conferir Tabarin (1622).
} 
vivant, e, ao contrário do final apoteótico, não tinha relação com o romance de Alencar. Denominado "A primeira missa no Brasil/ desembarque das tropas e comitiva de Pedro Alves [sic] Cabral" ("Circo Spinelli" 1906c, 3), fazia menção à portentosa pintura histórica de Victor Meirelles "A primeira missa no Brasil” (de 1861, portanto, contemporânea ao romance), pintura que valeu ao artista um prêmio do imperador e igualmente pertencia ao intuito da nova nação de construir os seus símbolos identitários (cf. Morettin 2000). Ao comparecer no espaço do circo cujo protagonista era um clown negro, a cena tem os seus significados redefinidos, e seu sentido original questionado - lembre-se que tal passagem já deu ensejo a corrosivas leituras alegóricas, como aquela presente em Terra em Transe (1967), de Glauber Rocha, na qual, aliás, igualmente comparece a trilha sonora de Il Guarany.

$\mathrm{Na}$ citada crônica que dedica ao Spinelli, Arthur Azevedo constata: "Não digo que a peça arrancasse exclamações de entusiasmo a José de Alencar e Carlos Gomes” (A. A. 1907, 2). Efetivamente, se o elemento espetacular está presente na obra de Gomes e mesmo na de Alencar (na qual o viés historiográfico dá mãos aos desvarios próprios ao Romantismo), o sentido da peça de Benjamin é todo outro, determinado pelo gênero teatral que a enforma, e pela sem-cerimônia com que se casam, nela, o popular e o erudito. Como esta característica acabará por resvalar à cena cinematográfica, tecerei a seguir uma análise comparativa entre a obra de Benjamin e aquelas que lhe serviram de modelo.

\section{Veredas do Guarani: o romance histórico, a opera ballo, a pantomima circense, a fita cinematográfica.}

Uma mudança fundamental da pantomima circense de Benjamin de Oliveira com relação ao romance de José de Alencar é o seu deslocamento da seara do drama - ou melodrama - em direção à farsa. Estudos recentes produzidos nos âmbitos das teorias da literatura e do teatro procuram dar conta do entremear, em obras com contornos semelhantes a $O$ Guarani, de características de gêneros literários considerados, segundo a hierarquia clássica, "baixos", como o folhetim jornalístico ou o melodrama teatral ${ }^{14}$. No

\footnotetext{
${ }^{14}$ Thomasseau tece as seguintes considerações sobre a questão, tomando como foco o melodrama teatral:

"Desta forma, reforçou-se uma hierarquia indiscutível e rigorosa de gêneros que colocava a tragédia no topo da pirâmide dos valores teatrais. Imediatamente após a Revolução, no imenso deslocamento político e social que se opera, os valores são redistribuídos, uma vez que a pirâmide das certezas estéticas, juntamente com aquela da sociedade, alterara-se a partir da base. O gênero melodramático, nascido naquela época, depois de ter rapidamente adquirido, graças ao surgimento de um novo público, a plenitude dos seus meios, encontrou-se de saída no centro de tensões contraditórias, atraindo conjuntamente o desprezo de detratores clássicos e românticos, mas também o fervor das multidões." (Tradução da autora). No original: "S'est de la sorte renforcée une indiscutable et stricte hiérarchie des
} 
que toca a esta obra de Alencar, é incontornável a sua aproximação dos cânones da literatura folhetinesca, impressa a granel em jornais e revistas desde princípios do século XIX. Observe-se, na construção da narrativa, a tipificação dos caracteres, a equiparação do âmbito moral e do físico das personagens (tornando-se, assim, a alvura e a envergadura física reflexos da limpidez moral, e o sarcasmo, a sensualidade e a impassibilidade reflexos das máculas morais $)^{15}$, a presença, entre um capítulo e outro, dos "ganchos" - síncopes narrativas cujo intuito é titilar a curiosidade do público para o que vem adiante -, e a relevância atribuída às cenas de ação, daí a prodigalidade com que as destrezas físicas do índio Peri colocam-se em exibição no romance, ou a prodigalidade com que se narram os episódios derradeiros da história: a tentativa de sequestro de Ceci por Loredano; a tomada da fortaleza de D. Antonio de Mariz pelos Aimorés e a fuga de Peri e Ceci entre a densa floresta dominada pelos indígenas e, finalmente, sobre a palmeira que vaga solitária sobre o túrgido Paquequer. $\mathrm{O}$ ritmo ágil da narrativa, a preponderância das cenas de ação e dos quiproquós narrativos ao burilamento poético do texto - enfim, a exacerbação do âmbito óptico dos episódios narrados - são elementos que aproximam este romance de exemplares populares da literatura e do teatro do Oitocentos, os quais enfatizam a visualidade da cena em detrimento do âmbito literário. Thomasseau (2009), um dos principais estudiosos do gênero, faz sobre ele as seguintes considerações:

É em torno dos anos de 1820 que o espírito dos dramas mudará no Boulevard. Sua qualidade essencial é, no entanto, a faculdade de comover menos pelas palavras que pelo olhar, assim como sublinha ainda Geoffroy, para quem a arte do teatro, a exemplo do que ocorria com seus contemporâneos letrados, é ainda e acima de tudo a arte da linguagem: "Tratam-se de espetáculos de óptica, de mecânica e de indústria mímica, absolutamente estrangeiros à arte do teatro propriamente dito; as palavras são deixadas de lado em prol do mercado, o que se diz é um acessório que não serve pra

\footnotetext{
genres qui plaçait la tragédie tout en haut de la pyramide des valeurs théâtrales. Immédiatement après la Révolution, dans l'immense brassage politique et social qui s'opère, les valeurs se redistribuent car la pyramide des certitudes esthétiques, avec celle de la société, a bougé de la base. Le genre mélo - dramatique, né à cette époque, après avoir très vite acquis grâce à l'émergence d'un nouveau public la plénitude de ses moyens, s'est alors d'emblée trouvé au centre de tensions contradictoires, s'attirant conjointement le mépris des zoïles classiques et romantiques mais aussi la ferveur des foules." (Thomasseau 2009, 8)

${ }^{15}$ Observem-se as descrições de Loredano nas passagens a seguir: "Loredano não pôde reprimir a risada sardônica que lhe veio aos lábios."; "Os olhos do italiano lançaram uma faísca; mas o seu rosto conservou-se calmo e sereno."; "A fisionomia de Loredano não se alterou, e conservou a mesma impassibilidade; apenas o seu ar de indiferença e sarcasmo desapareceu sob a expressão de energia e maldade que lhe acentuou os traços vigorosos." (Alencar 1857, 26, 27, 30)
} 
nada; o que se vê é essencial, é para isso que se paga." (Thomasseau 2009, 38. Tradução da autora. $)^{16}$

A crítica citada pelo estudioso num só tempo explicita a dimensão óptica incontornável aos gêneros teatrais de cunho popular - a exemplo do melodrama -, quanto, ao trazer as verrinas que os letrados do período lhes dirigiam, relaciona o conjunto de gêneros desconsiderados pela crítica. Este volume de Thomasseau, compêndio de ensaios que se debruçam sobre peças fundamentais do repertório melodramático francês, é um manancial para o estudo do teatro do século XIX, testemunhando o desabrochar de uma cultura cada vez mais voltada para a visualidade, que, nos estertores do século, teria no cinema um dos seus mais importantes desdobramentos. As análises que ele propõe a exemplares do gênero melodramático nos permitem entrever as semelhanças entre tais obras e um romance como $O$ Guarani, parido como obra séria, imbuído de missão histórica e nacionalista.

A emergência visual do romance de José de Alencar determinou a sua extração não apenas à cena operística, por Carlos Gomes, como à teatral, numa variante da obra que, embora seja hoje pouco conhecida (já que jamais veio ao prelo), foi igualmente bem sucedida junto ao seu público contemporâneo. Ambas, a ópera e a peça, têm em comum o investimento na espetacularidade. Classificada a primeira como "opera ballo"17, igualmente reduz o número de personagens. As vozes/ tipos principais são Peri (tenor), Cecília (soprano), D. Álvaro (tenor), D. Antonio de Mariz (baixo) e Gonzales (barítono) - como se vê, a tipologia das personagens exacerba-se a partir dos timbres dos cantores, à maneira do melodrama, a vilania intensificando-se pela gravidade do timbre do barítono. Outra personagem secundária é Pedro, homem de armas de D. Antonio, cuja identidade com o patrão se estabelece pelo compartilhamento do timbre do baixo. Todas personagens, como pudemos observar, transpostas à pantomima de Benjamin de Oliveira - note-se, todavia, a alteração na nacionalidade do vilão da história, espanhol ao invés de italiano (provável concessão de Carlos Gomes ao país que o acolheu e estreou a sua produção) $)^{18}$. Redigido quatro anos mais tarde, o drama toma como modelo menos o romance que a ópera, para a qual já havia sido realizado um bem-

\footnotetext{
${ }^{16}$ No original: "C'est autour des années 1820 qu'au Boulevard, l'esprit des drames va changer. Leur qualité essentielle demeure cependant la faculté d'émouvoir moins par les mots que par le regard, ainsi que le relève encore Geoffroy pour qui l'art du théâtre, comme pour tous ses contemporains lettrés, est encore et d'abord celui du langage: 'Ce sont des spectacles d'optique, de mécanique et d'industrie mimique, absolument étrangers à l'art du théâtre proprement dit ; les paroles y sont par dessus le marché ce qu'on y dit est un accessoire compté pour rien ; ce qu'on y voit est l'essentiel, c'est cela que l'on paie."'

${ }^{17}$ Il Guarany (1870), opera ballo/melodrama em quatro atos, com música de Carlos Gomes e libreto de Antônio Scalvini e Carlo d'Ormeville. (Scalvini, Ormeville 1870)

${ }^{18}$ Il Guarany estreou no prestigioso Teatro alla Scala, de Milão.
} 
sucedido enxugamento da trama. Isto não significa que o drama ou a ópera deem de ombros ao texto original, malgrado José de Alencar tenha publicamente demonstrado repúdio à encenação da peça e mesmo esboçado reservas, em âmbito privado, à ópera. No que toca à criação de Carlos Gomes, ele teria dito a Taunay: "O Gomes fez do meu Guarani uma embrulhada sem nome, cheia de disparates, obrigando a pobrezinha da Ceci a cantar duetos com o cacique dos Aimorés, que lhe oferece o trono da sua tribo, e fazendo Peri jatar-se de ser o leão das nossas matas" (Faria 1982, 60). ${ }^{19}$

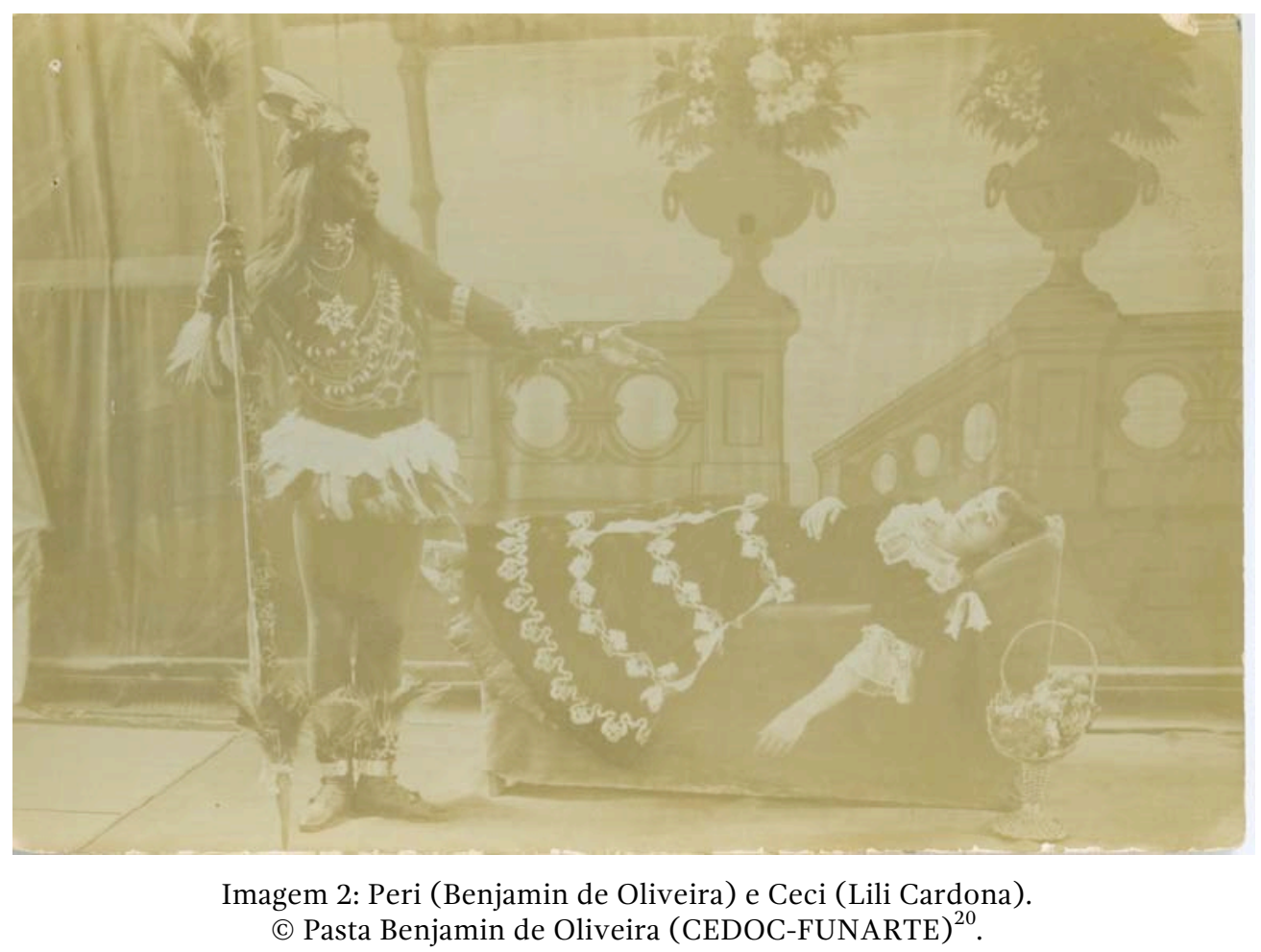

O autor toca numa questão fulcral ao âmbito melodramático, que, embora esteja presente no romance - ainda que de forma mais sutil -, exacerba-se na ópera: o investimento na subjetividade, transformada em chave de acesso à coletividade; a narrativa historiográfica filtrada pelas paixões individuais. Enquanto no romance Peri e Ceci são construídos como polaridades

\footnotetext{
${ }^{19}$ João Roberto Faria realiza um pormenorizado levantamento da questão. No que toca à reação do escritor frente à encenação da ópera de Carlos Gomes, findo o espetáculo, Alencar teria recebido "educadamente" a parte que lhe coube das demonstrações populares: enquanto que o maestro fora chamado à cena uma dezena de vezes, carregado em apoteose por uma plateia em êxtase e recebido pessoalmente congratulações de D. Pedro II, o romancista fora visitado pela mocidade efusiva, a quem agradecera e louvara as qualidades. A confissão sobre seu desagrado no que toca à produção se dera, sobretudo, aos amigos pessoais (Faria 1982).

20 Agradeço à instituição pela cessão dos direitos de uso, neste artigo, desta imagem e da seguinte.
} 
diametralmente opostas, ambos altamente idealizados (a deusa virgem e seu escravo submisso), funcionando como alegorias respetivamente do europeu e do povo autóctone - sugerindo-se a sua aproximação carnal apenas quando o índio adere à fé cristã e, portanto, se dobra ao colonizador -, na ópera as duas personagens enquadram-se à moldura convencional do gênero, transformadas desde o princípio no par romântico protagonista. ${ }^{21}$ Isto se explicita no notório primeiro dueto de ambos, prenhe de lirismo. Observe-se, no entrecho que se segue, que a simultaneidade da melodia e dos versos do dueto (outra característica sine qua non da ópera tradicional italiana, cf. Abbate e Parker, 2015) simboliza um encantamento romântico compartilhado: Peri: "Sinto uma força indômita/ que a cada hora mais me aproxima de ti,/ mas não a posso exprimir,/ nem te dizer por quê./ Sei que uma só palavra tua, ó virgem/ um sorriso teu, um olhar/ como um dardo afiado,/ ferem o meu coração.”; Cecilia: “(Eu também, eu também em vão/ imploro a mim mesma a cada hora/ o que é essa sensação angelical,/ que me comove o coração./ O seu olhar tão vívido/ Sinto refletido em mim,/ em vão eu me questiono,/ mas não sei dizer para mim mesma por quê.)"22. (Tradução da autora. Scalvini; Ormeville 1870, 11).

Alencar menciona com igual amargura o dueto de Ceci com o cacique dos Aimorés, cena inexistente no romance, outra convenção do gênero operístico, cuja excelência determina-se pela tessitura da relação contrapontística das vozes. Embora a obra de Carlos Gomes também respondesse ao intuito de construção de uma memória nacional de cunho laudatório, fomentada pelo Instituto Histórico e Geográfico Brasileiro - fazendo-o ademais desde um centro cultural europeu, o que lhe potencializava a relevância -, fazia-o balizado pelas regras do gênero que manejava. Além do citado dueto entre Ceci e o Cacique, a obra de Carlos Gomes tem um extenso ballet indígena (coreografado à la europeia), correspondente aos ritos antropofágicos da tribo Aimoré no desfecho dos quais Peri pereceria, o qual cumpre com a espetacularidade requerida pelo gênero. Em suma, Gomes estabelece com o romance uma relação de liberdade, servindo ao gênero no interior do qual trabalhava.

\footnotetext{
${ }^{21}$ A história da ópera italiana centraliza-se nas paixões de apenas um casal protagonista, daí ser eliminado da cena o par Isabel e Álvaro - menos idealizado no romance, ainda que igualmente alegórico (ela, a mameluca passional, resultado da relação do colonizador com a índia; ele, o europeu por ela seduzido - relação que mimetiza a miscigenação do povo brasileiro). Isto faz com que certos contornos deste casal sejam transpostos ao par Peri e Ceci.

${ }^{22}$ A tradução tem o intuito de facilitar a compreensão do texto. Não se deve perder de vista, todavia, que os versos originais são cantados em italiano: Peri: "Sento una forza indomita/ che ognor mi tragge a te;/ ma non la posso esprimere,/ né ti so dir perchè./ So che un tuo detto, o vergine,/ un tuo sorriso, un guardo,/ come un acuto dardo,/ scende a ferirmi il cor.../". Cecilia: "(Io pure, io pure invano/ chieggo a me stessa ognor/ che è mai quel senso arcano,/ che mi commuove il cor./ Lo sguardo suo sì vivido/ sento riflesso in me;/ ma invan me stessa interrogo,/ ma né mi so dir perchè.)"
} 
As conexões temáticas e formais existentes entre a ópera e o melodrama teatral determinam as semelhanças entre Il Guarany de Carlos Gomes e a obra homônima de Visconti Coroacy e Pereira da Silva. Aliás, o repertório operístico erudito historicamente desce de bom grado aos palcos populares, não só melodramáticos como cômicos, amoldando-se igualmente bem às telas, como terei a oportunidade de demonstrar ao longo deste artigo. ${ }^{23}$ A estreia da extração teatral de $O$ Guarani é anunciada para 9 de maio de 1874 , após uma extensa polêmica envolvendo os autores, a companhia de Heller - onde se daria a encenação - e José de Alencar ${ }^{24}$. Tratava-se, segundo o anúncio publicado no Jornal do Comércio, de um "drama de grande espetáculo, em um prólogo, quatro atos e onze quadros extraído do romance do mesmo título com o consentimento do autor o Exmo. Sr. Conselheiro José de Alencar, por Visconti Coroacy e Pereira da Silva, música do maestro Carlos Gomes" (Teatro Lírico Fluminense... 1874a, 6) - observem-se destacadas tanto a permissão do autor do romance à sua versão teatral quanto a utilização da música da ópera.

Desdobrado à cena dramática, $O$ Guarani explicita a sua inconteste filiação com a cena operística. Além da presença da música de Carlos Gomes a pontuar a ação (ensaiada e conduzida pelo maestro Mesquita), a encenação procurava sublinhar seu âmbito espetacular, demonstrando a veracidade do que assevera Victor Hugo no Prefácio de Cromwell: "le théâtre est un point d'optique" (apud Thomasseau 2009, 24). No conjunto de quadros citados abaixo, observe-se o destaque dado àquele que se denomina "Campo dos Aimorés", composto por uma vasta sequência de bailados que nada deviam à ópera de Gomes, nos quais tomava parte um vultuoso número de pessoas. Dignas de nota são também as cenas pertencentes ao âmbito do maravilhoso, fundamentais a gêneros teatrais de cunho popular, a exemplo das peças fantásticas (também denominadas "mágicas"), cujos enredos estavam num segundo plano, em detrimento das encenações faustosas (Mencarelli 1999) o anúncio do espetáculo destacava os responsáveis pelo vestuário, adereços e maquinismos da peça, o que atestava a sua dimensão espetacular:

Prólogo e primeiro quadro: O Segredo das Minas/ $2^{\circ}$ quadro: O Mar de Prata $/ 3^{\circ}$ quadro: Palácios Encantados/ $1^{\circ}$ ato -4 . quadro: $\mathrm{O}$ Guarany $/ 2^{\circ}$ ato -5 . quadro: Os Aventureiros $/ 3^{\circ}$ ato -6 . quadro: Desafio e Traição/ $7^{\circ}$ quadro: A Revolta/ $8^{\circ}$ quadro: A Seta do Índio $/ 4^{\circ}$ ato -9 . quadro: O Campo dos Aimorés: Neste quadro, em que tomam parte mais de 250 pessoas, executar-se-ão: A banda selvagem; Os grandes bailados; O passo das flechas; A marcha dos

\footnotetext{
${ }^{23}$ Faz-se preciso sublinhar aqui que a presença do repertório musical erudito no Rio de Janeiro da aurora do século XX era intensa e ultrapassava a barreira das classes sociais, ao contrário do que se dá hoje.

${ }^{24}$ Para detalhes sobre a polêmica, remeto o leitor ao já citado ensaio de Faria (1982).
} 
Aimorés; A corrida veloz e fantástica; A grande entrada triunfal; O Cacique no seu palanquim; Entrada dos aventureiros; Combate final; tudo ensaiado pelo 1 . bailarino Poggiolesi que toma parte em todos os bailados em companhia da 1a bailarina Bernardelli./ $10^{\circ}$ quadro: A Explosão/ $11^{\circ}$ quadro: A Inundação/ O rio Paquequer em ocasião de enchente a sumir-se ao longe iluminado pelo Arco-Íris. Peri e Cecília, abraçados, são levados pela corrente sobre o grelo de uma palmeira. (Teatro Lírico Fluminense 1874b, 6)

O repúdio de José de Alencar à peça - uma das cláusulas do contrato que assinara com os autores e o empresário da Fênix Dramática proibia a publicação de seu texto - procurava escamotear a proximidade existente entre a versão teatral e a obra original. Embora as adaptações sejam fruto de uma seleção, é digno de nota que mesmo as cenas mais extravagantes desta peça sejam exploradas ou sugeridas pelo romance caudaloso, composto de mais de 700 páginas e quatro partes paulatinamente narradas, numa tradição que remete ao roman-fleuve produzido por autores como Honoré de Balzac e Victor Hugo. ${ }^{25}$ Obra dada não apenas aos arroubos sentimentais como à serialização, duas premissas caras ao cinema narrativo que, desde o princípio do século XX, nutre-se da literatura como dela se nutrira o teatro, no século anterior. As inúmeras cenas do romance voltadas à exploração das destrezas físicas de Peri ou aos idílios de Ceci às margens do (ou sobre o) Paquequer, prenhes de visualidade, realizam-se à perfeição pelo teatro popular, já que são a sua razão de ser.

O final apoteótico do romance, no qual o barco que conduz Ceci e Peri desliza frágil na cheia do Paquequer, é espaço por excelência para que o "Sr. Caetano", o maquinista da Fênix, esgrima os seus dotes - afirma Jean-Marie Thomasseau que o uso cênico das inundações com fins dramáticos ou espetaculares passa a ser recorrente às encenações teatrais de cunho popular, a partir de fins do XIX $^{26}$. Ademais, a encenação da obra foi realizada pelo principal artífice do teatro popular em ação no Rio de Janeiro nos anos de 1870, Correia Vasques - o popularíssimo, alcunha que vale por uma descrição completa -, homem que comporta grandes semelhanças com Benjamin de Oliveira, conforme aponta Silvia Souza: Artista multifacetado, ator, encenador e autor - é dele a autoria da

\footnotetext{
${ }^{25}$ Remeto o leitor à primeira edição da obra, que compõe a coleção da Biblioteca Brasiliana, disponível para download e consulta online no link citado na Bibliografia.

${ }^{26}$ O estudioso reporta-se a um caso notório: o concernente ao melodrama Os dois garotos (Les Deux Gosses, Decourcelle, Berton, 1896), grande sucesso mundial, no qual o cenário da eclusa da Ponte D'Austerlitz - que utilizava água verdadeira obrigou à importação de maquinário da Inglaterra (Thomasseau 2009, 271). No Rio de Janeiro, espetáculos do tipo eram igualmente comuns. No mesmo dia em que a pantomima cinematográfica Os Guaranis era exibida no Cinema-Palace, a Companhia Equestre Frank Brown fazia exibir, no Teatro S. Pedro de Alcântara, a "pantomima aquática" O S. Pedro Debaixo d'água, "com extraordinários incidentes e diversões, terminando com uma assombrosa torrente, inundando a pista em 35 segundos 100.000 litros d'água." "“Teatro São Pedro de Alcântara...” 1908, 6).
} 
adaptação à cena brasileira da obra de Jacques Offenbach Orphée aux enfers (transformada em Orfeu na roça), obra que, por meio de um denso exercício metatextual, fazia bulha num só tempo da mitologia grega e do sisudo teatro realista (Souza 2002, 234-239). Transformado no encenador do teatro Ginásio Dramático, não demorou ao artista fazer ali uso dos talentos adquiridos nos teatros de feira em que se exercitara quando jovem, encenando peças que estabeleciam relação intertextual com a cena teatral do período, a exemplo daquelas alusivas ao "Grande Circo Oceano", então na cidade. A homenagem, prestada no recinto que era o berço brasileiro da dramaturgia realista, num só tempo conferia relevância àquele grupo circense e procurava absorver a multidão que frequentava o estabelecimento (Sousa 2002, 246-247).

Quando o igualmente popular Benjamin conduziu a trupe do Circo-teatro Spinelli pela esteira do Guarani, ele tinha atrás de si uma vicejante tradição teatral popular, para a qual o repertório erudito é fonte de apropriação e ressignificação. As semelhanças existentes entre as adaptações do romance à ópera e ao teatro colocavam em xeque a dicotomia estrita que, segundo a tradição clássica, separava os gêneros entre "altos" e "baixos". Mesmo Carlos Gomes não era infenso à mescla. Um analista seu, um século depois da estreia de sua ópera, diria - de modo, aliás, detrator - que o seu já mencionado ballet estabelecia "uma frequente e perigosa vizinhança com música de circo" (Kiefer 1977, 95). Na cena teatral do século XIX havia, como se nota, uma permeabilidade entre os gêneros, explicitada por meio da vizinhança que certos trechos da música de Gomes estabeleciam com os espetáculos circenses, da inserção dos principais trechos musicais da ópera Il Guarany no melodrama homônimo, ou das paródias do repertório exibido na cidade que Vasques levava à cena do Ginásio Dramático nos idos de 1860. Como sensível observador da ópera de Gomes e continuador espiritual de Vasques, Benjamin de Oliveira levou a sua encenação a construir uma relação metadiscursiva com a obra-fonte, reinterpretando-a.

É impossível precisarmos como isso se deu, já que, conforme foi apontado, os registros remanescentes a esse respeito são raros. Mas as imagens disponíveis da encenação (Imagem II e III) dão a ver, à maneira de tableaux, um Peri galardoado e uma Ceci ora passivamente prostrada, ora a entoar uma prece, tendo de um lado o índio a protegê-la e, de outro, o aventureiro espanhol (como se pode observar, sua nacionalidade alterara-se, quando comparada à montagem de 1902) a intimidá-la. Ao fundo, um cenário pintado simboliza a murada da fortaleza de D. Antonio de Mariz. Encenação sem diálogos, à moda da pantomima clássica - o que leva certo espectador fluminense a solicitar, em 1906, a publicação de sua "explicação" por parte do encenador ${ }^{27}$-, a criação de Benjamin apela

27 "Circo Spinelli: Tem agradado muito a pantomima Os Guaranis, e muito satisfeitos ficariam os espectadores se o ensaiador Benjamin de Oliveira publicasse 
à memória coletiva. Já o estatismo dos tableaux remete ao gênero melodramático, demasiado conhecido das plateias de então.

A análise de um objeto evanescente como a película Os Guaranis convida-nos a colocá-lo em diálogo com outras obras análogas contemporâneas que sobreviveram ao tempo. Dois artigos de The sounds of the early cinema debruçam-se sobre a questão. John Fullerton analisa comédias dinamarquesas anteriores ao ano de 1910, atentando para a existência, nelas, da "experiência auditiva do circo". $\mathrm{O}$ autor analisa a presença sonora naqueles filmes a partir de um duplo viés: na figuração do som no interior da diegese fílmica e na introdução dos elementos sonoros a partir do âmbito da sala de exibição. Assim, os jump cuts $^{28}$ sincronizavam-se às inserções sonoras, ambos relacionando a espectatorialidade fílmica à circense: "os sons e os saltos estimulariam uma resposta multimedial no espectador, trazendo alguns dos eventos auditivos associados à performance circense à experiência de se assistir a um filme" (Fullerton 2001, 90) ${ }^{29}$. Por seu lado, Dominique Nasta reflexiona sobre os melodramas fílmicos anteriores a 1915, norte-americanos e europeus. No que toca aos filmes norte-americanos, destaca a presença incontornável de música e sons, tanto como pano de fundo emocional às ações quanto no anúncio das "pausas da ação ou interlúdios extra-fílmicos”, à maneira dos melodramas teatrais e operísticos que lhe serviram de modelo. Já no que se refere aos filmes europeus, a autora constata que os modelos anteriores fossem teatrais, fossem operísticos - ofereceram influências menos no âmbito conteudístico e mais no estilístico. Debruçando-se sobre a grande presença de sons figurados na diegese fílmica, sobre as "reações auditivas" de personagens aos sons encenados em película estimulando, no público, o âmbito auditivo a partir do óptico -, Nasta aponta para o comparecimento, naquelas fitas, da "moral oculta" do gênero melodramático ${ }^{30}$ : "o ato de ouvir ou escutar frequentemente permite tanto aos protagonistas quanto à audiência considerar o som a chave à transcendência, à subjetividade mental ou à psicologia da personagem.” (Nasta 2001, 96). ${ }^{31}$ A presença

uma explicação sobre ela, a fim de melhor orientar o público./ Esperamos ser atendidos./ Pagante \& C." ("Circo Spinelli" 1906b, 3).

${ }^{28}$ Também conhecido como raccord ou salto, trata-se da montagem de dois planos a partir de uma mesma tomada, removendo-se parte do interior da mesma, o que gera uma transição brusca entre eles e o efeito de "salto" na ação. (Aumont e Marie 2003).

${ }^{29}$ Tradução da autora. No original: "sound and the jump cut would have stimulated a multimedial response in the historical spectator, bringing some of the aural events associated with live circus performance to the experience of viewing the film."

${ }^{30}$ Palavras de Peter Brooks, que a autora recupera (Brooks 1976, 20-21, apud. Nasta 2001, 96).

${ }^{31}$ Tradução da autora. No original: "the very act of hearing or listening frequently allows both the protagonists and the audience to consider sound as the key to transcendence, to mental subjectivity or to character psychology." 
indelével da música no melodrama remete, ademais, para a aceção histórica do gênero: obra dramática cujo texto é acompanhado de música.

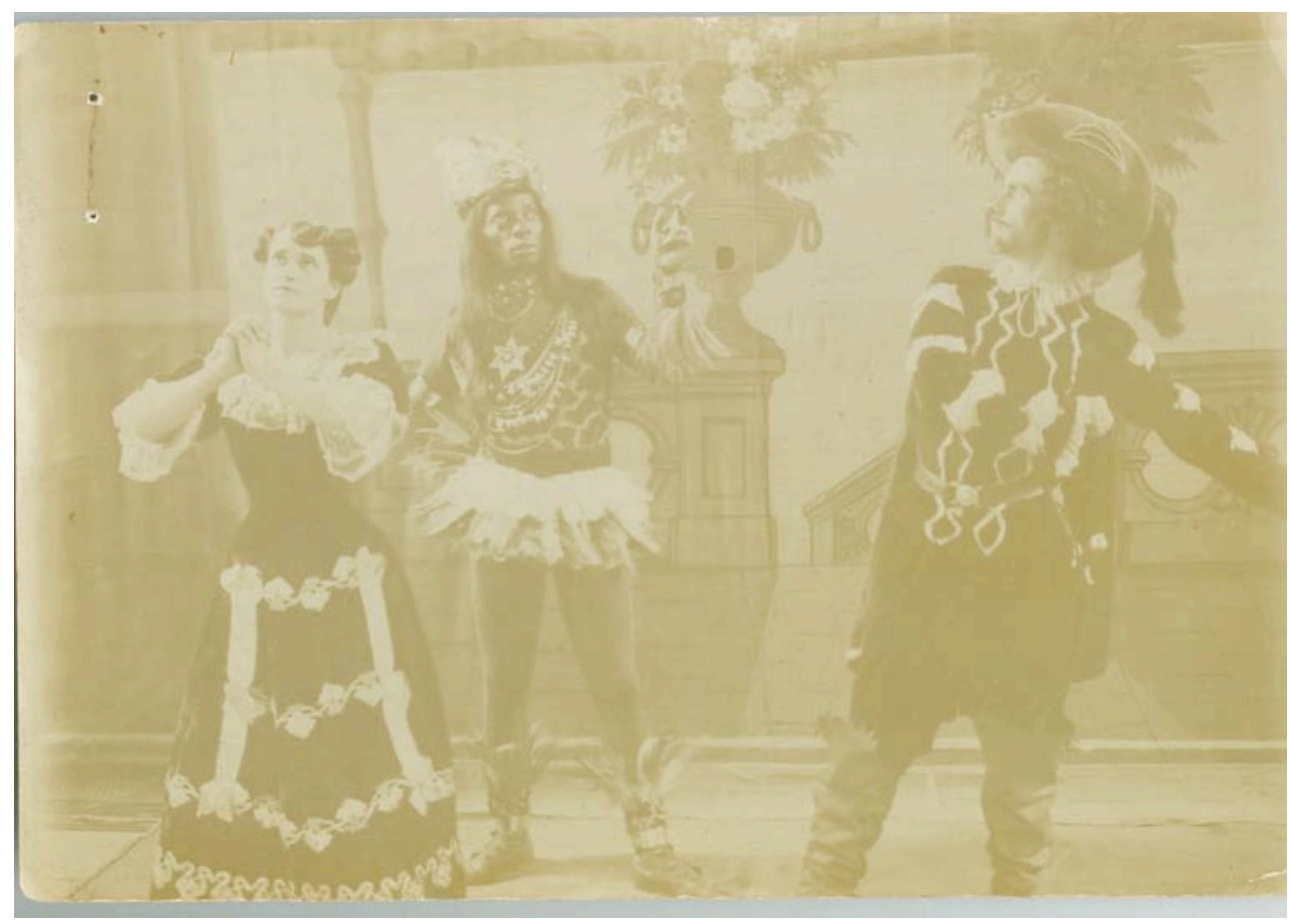

Imagem 3: Peri (Benjamin de Oliveira), Ceci (Lili Cardona) e o aventureiro espanhol (Cardona) $)^{32} \mid$ (c) Pasta Benjamin de Oliveira (CEDOC-FUNARTE).

Os registros históricos que nos chegaram acerca d'Os Guaranis de Benjamin de Oliveira remetem-no, como vimos, tanto à farsa quanto ao melodrama. $\mathrm{O}$ analista incauto corre o risco de alinhar os picadeiros estritamente ao âmbito farsesco, deixando de lado uma questão fundamental: a farsa cáustica e o mais pungente melodrama - ou seja, o entremear de humor e drama - eram consubstanciais aos circos d'outrora. ${ }^{33}$ O lirismo da música de Carlos Gomes, presente fosse na memória coletiva do público, fosse empiricamente - pela execução da banda do Cinema-Palace -, cooperava na construção dos sentidos, aproximando afetivamente, a priori, aquele negro que se fazia de índio e a jovem branca que com ele contracenava: forjandose simbolicamente uma nova identidade nacional, que dava ao negro o protagonismo historicamente negado. Após reportar-se às "aventuras idílicas" das duas personagens, Arthur Azevedo aproxima Benjamin doutra personagem célebre, prenhe de densidade dramática: "um negro que, metido nas suas bombachas de clown, me

\footnotetext{
${ }^{32}$ A referência ao intérprete desta última personagem nos é fornecida por Lili Cardona, no verso da fotografia (Pasta Benjamin de Oliveira).

33 Tais características são percebidas hoje em espetáculos brasileiros como Pagliacci, da companhia circense La Mínima (La Mínima, 2017), ou Maria do Caritó (dirigido por João Fonseca e produzido por Fernando Neves em 2010), alinhados ao circo-teatro tradicional.
} 
pareceu Otelo, que saltasse das páginas de Shakespeare para um circo da Cidade Nova." (A. A. 1907, 2). O clown ganhara realeza shakespeareana.

A relevância de Benjamin de Oliveira na cena teatral do período fomentaria o convite para que ele e a trupe do Circo-teatro Spinelli interpretassem a pantomima diante da objetiva de Antonio Leal, da Photocinematografia Brasileira. Vicente de Paula Araújo, um dos historiadores pioneiros do cinema brasileiro do período, afirma que a filmagem deu-se no Spinelli, com câmera imóvel (Araújo 1976, 264). Enquanto que a assertiva acerca da posição da câmera provavelmente esteja correta, não é impossível que a fita tenha sido rodada no estabelecimento de outro de seus produtores, Labanca, afamado fotógrafo, cujo ateliê de vidro costumava frequentar as páginas de anúncios das folhas cariocas. Júlio Ferrez, outro cinematografista pioneiro da cidade, redige umas memórias saborosas sobre o espaço, quando narra detalhes concernentes à encenação de uma fita sua ali rodada um ano mais tarde, A Viúva Alegre.

$\mathrm{Na}$ Rua dos Inválidos havia um atelier envidraçado do Sr. Labanca que serviu para diversos filmes, inclusive um filme nacional $A$ Moreninha feito pelo Leal. Aproveitei deste studio assaz vasto para poder movimentar uma troupe de opereta. Não se conhecia ainda os primeiros planos para os artistas principais, assim mesmo delimitava a ação com giz no chão obrigando as vedetes a vir cantar à frente ${ }^{34}$.

O que Júlio Ferrez diz sobre A Viúva Alegre - uma das obras comercialmente mais bem-sucedidas da época - ajuda a iluminar uma fita como Os Guaranis, sobre a qual as informações são escassas. A proximidade dos atores com relação à câmera atesta que o cinema brasileiro já havia deixado de lado o plano aberto, tributário do ponto de vista do espectador teatral, como escolha unívoca. Isto nos remete novamente às Imagens 2-3 - é provável que tais fotografias mimetizassem o registro cinematográfico das cenas, tomando-se as personagens num plano mais aproximado, como se eles se chegassem ao proscênio, à maneira como se dava nas phonoscènes da Gaumont. $^{35}$ Caso Os Guaranis tenha sido rodado no atelier de Labanca, é provável que as limitações do espaço obrigassem à supressão da célebre cena da inundação, aproximando-se a fita de forma mais cerrada da versão operística do romance. A redução faria jus às características técnicas do filme: nas memórias supracitadas, Júlio Ferrez faz menção à existência, então, de rolos de película de

\footnotetext{
${ }^{34}$ Cf. Arquivo Nacional: Fundo Família Ferrez - Júlio Ferrez: FF-JF: 2.0.2, documento $5 / 2$.

${ }^{35}$ Tais fitas correspondem a alguns dos primeiros esforços de sincronização entre o cinematógrafo e o fonógrafo. Os cantores eram filmados segundo a encenação teatral: surgiam em cena, cantavam o número que lhes cabia e se retiravam, retornando ocasionalmente à cena para receberem os aplausos da plateia exterior à diegese fílmica. A este respeito, conferir Carvalho (2017).
} 
no máximo 60 metros, o que lhe obrigara a atentar para a duração dos números de canto de uma obra longa como A Viúva Alegre (com cerca de 1000 metros de extensão, ou cerca de 1h00 de duração, caso o filme tenha sido projetado na velocidade de $16 \mathrm{q} / \mathrm{s}^{36}$ ) em relação à extensão dos rolos, cuidando para que cada rolo terminasse "num compasso firme" (Firma Família Ferrez), de modo a conseguir-se um bom efeito de continuidade nos momentos de troca dos rolos.

Enquanto A Viúva Alegre ocupava todo um programa cinematográfico, Os Guaranis toma a parte final de programas compostos por quatro fitas (como se observa na Imagem 1), transformando-se, assim, no ponto culminante dos espetáculos. Considerando que o programa exibido pelo Cinema Palace possuía aproximadamente a duração de A Viúva Alegre; considerando-se, ademais, o tempo gasto na troca das quatro fitas do programa, supõese que cada fita media cerca de 180-240 metros de extensão. Assim, Os Guaranis durava aproximadamente 9-12 minutos ${ }^{37}$, a ação sendo condensada nos principais episódios que funcionavam, como já apontei, à guisa de tableaux vivants (como bem explicitam as Imagens 2 e 3); quadros tributários do teatro melodramático, que levavam a emoção a um paroxismo. Misto de farsa e drama, oferecia à orquestra a ocasião de fechar cada programa com os compassos altissonantes da música de Gomes, à maneira do que ocorria nos programas teatrais dos tempos de Correa Vasques.

\section{Considerações finais: um tecido cultural}

A relação intermidial estabelecida no século XIX entre romance e teatro encorpa-se, no século XX, com o advento do cinematógrafo. Examinando-se as folhas de 1908, observamos que "Guaranis" variados conviveram na cena carioca: sendo a fita Os Guaranis ora exibida no Cinema-Palace concomitantemente à récita da ópera de Gomes, pela "Grande Companhia Lírica Italiana” que então ocupava o Teatro Apolo ("Cinema-Palace" 1908b, 20; "Teatro Apolo...” 1908, 20); ora exibida no dia anterior à apresentação de ambas a pantomima Os Guaranis, no Circo-teatro Spinelli, e a ópera de Carlos Gomes, pela mesma companhia italiana, agora no palco do Teatro São Pedro de Alcântara. Os sentidos da fita da trupe de Benjamin construíam-se nesses meandros, na polifonia sonora que ressoava na metrópole - polifonia que as telas do Cinema-Palace sublinhavam, já

\footnotetext{
${ }^{36}$ Conforme Júlio Ferrez descreve nas supracitadas memórias, A Viúva Alegre tinha "cerca de mil e tantos metros" (cf. Arquivo Nacional: Fundo Família Ferrez Júlio Ferrez: FF-JF: 2.0.2, documento 5/2). Na Tabela de metragens apresentada por Usai em Silent Cinema: an introduction (2000), um filme $35 \mathrm{~mm}$ (fora utilizada nas filmagens de A Viúva Alegre uma câmera Pathé, que utilizava rolos de $35 \mathrm{~mm}$ ) com extensão de 1000 metros comporta, quando exibido na velocidade de 16 quadros por segundo, 55 minutos de duração (Usai 2000, 170-174).

${ }^{37}$ Segundo a supracitada tabela, cada $60 \mathrm{~m}$. de fita projetados a $16 \mathrm{q} / \mathrm{s}$ tem a duração de 3,16 min. (Usai 2000, 170-174).
} 
que a orquestra devia desdobrar-se em ritmos vários, a acompanhar as fitas de temáticas e gêneros díspares que corriam pelo pano.

Esta mencionada variabilidade de registros fazia os programas dos cinematógrafos remeterem àqueles dos circos e dos teatros populares (ou circos-teatros), tão desdenhados pela hierarquia clássica. Adaptada pela orquestra do Cinema-Palace, provavelmente com base na extração da partitura da ópera à banda circense (realizada pelo maestro Irineu de Almeida), a partitura de Carlos Gomes conviveria com temas musicais populares, cabíveis à grande quantidade de fitas cômicas que preenchiam os programas. Há que se considerar igualmente, à luz do que aponta Kiefer, o flerte que a própria música de Gomes estabelecia, vez por outra, com o repertório circense - considerá-lo não para desprestigiar o fato, mas para ainda uma vez ratificar o amálgama: a mescla de erudito e popular que o analista critica em Gomes é um dos elementos que tingiu de cor local a sua música tipicamente europeizante.

Inserida no seio do cinematógrafo, esta característica da música de Carlos Gomes seria de novo sublinhada. Embora a partitura utilizada no Cinema Palace não tenha sido conservada, aventamos a seguir uma reflexão sobre o provável acompanhamento musical da fita, na esteira do que aponta Martin Marks em Music and the Silent Film (1997): supondo-se que a orquestra do Palace tenha adaptado os propalados "22 números" de música da encenação do Spinelli à fita rodada por Leal, podemos cogitar sobre quanto a costura de tão variado conjunto de temas, em blocos descontínuos, no interior de uma fita curta, não favorecia a sua aproximação à esfera da pantomima. Tais considerações tomam como base a análise que Marks empreende na partitura de An Arabian Tragedy, filme curto de 1912 que narra, de modo fragmentário - mimetizado pela música que fora composta para ele -, uma larga quantidade de episódios concernentes à tragédia em questão. Afirma Marks: "Com tantas mudanças [fragmentos musicais escritos para se fecharem em si mesmos, na esteira das sequências fílmicas que desenhavam o passo a passo da tragédia] a música parece-se pantomímica." (Marks 1997, 83). A cena cinematográfica/musical que abriga Os Guaranis é, portanto, tão miscigenada quanto o herói de Benjamin de Oliveira.

Entre fins de 1908 e o início de 1909, principia-se a rodagem de fitas falantes nacionais, nas quais a voz que correspondia à mímica apresentada na tela era emitida ao vivo, por artistas velados pelo pano branco. Tais fitas eram eminentemente musicais e reproduziam trechos do repertório popular e erudito, que já experimentavam sucesso de público, nos teatros e nas ruas. Entre eles, dois são extraídos da ópera de Gomes, A Canção do Aventureiro (1908) e o Dueto do Guarany (1909), ambos produzidos por William Auler, dono de uma fábrica de móveis e serraria que resolve não apenas investir no ramo da exibição (é de sua propriedade o Cinematógrafo Rio Branco) como patrocinar a rodagem de "fitas falantes nacionais" 
- o berço plebeu que acalentou o cinema da alvorada do século XX foi decisivo nessa sua vocação à heterogeneidade ${ }^{38}$.

Por meio de uma pesquisa de viés transdisciplinar, procurouse demonstrar a relação que historicamente o cinema estabeleceu com a produção cultural de seu tempo. Daí a explicitada proximidade entre a estrutura dos programas cinematográficos da época do primeiro cinema e dos espetáculos teatrais populares, um e outro mesclados e descosidos, e embalados por uma polifonia musical que integrava o repertório erudito e o popular, igualmente amados pelo público, então. O fato de o cinematógrafo no Brasil ter sido, neste período do qual me ocupo, um entretenimento sobretudo do operariado, das camadas médias da população e da elite, demonstra quão importante ele foi na apresentação de alternativas ao imaginário oficial de nação, bem como na veiculação de outros escopos de criação artística para além da seara da arte erudita, donde o papel fundamental desempenhado por figuras como o clown Benjamin de Oliveira.

\section{BIBLIOGRAFIA}

s.a.. 1871. "Publicações a pedido: Elemento servil". Jornal do comércio, Rio de Janeiro, 27 ago., 4.

A. A. (pseud. de Arthur Azevedo). 1907. "Palestra”. O País, Rio de Janeiro, 23 fev., 2.

Abbate, C. E R. Parker. 2015. Uma história da ópera: os últimos quatrocentos anos. Tradução Paulo Geiger. São Paulo: Companhia das Letras.

\footnotetext{
${ }^{38}$ Em 27 de outubro de 1908 - portanto, um mês depois de estrear Os Guaranis cinematográfico -, William Auler estabelece um contrato com Júlio Ferrez (filho do notório fotógrafo Marc Ferrez, dono do Cinema Pathé) no intuito de patrocinar a rodagem de "fitas falantes nacionais". Auler explica as bases do acordo em carta enviada à firma Marc Ferrez \& Filhos:

De acordo com o que foi combinado verbalmente entre o seu sócio o Sr. Julio Ferrez e o nosso Sr. Christovão William Auler, para o fornecimento de fitas falantes nacionais; pela presente autorizamos a Vs. Ss. darem começo à sua confecção, fornecendo Vs. Srs. as fitas virgens necessárias e nós os artistas.

Fica acordado que Vs. Ss. nos fornecerão duas (2) fitas falantes por semana, à razão de dois mil e quinhentos réis (Rs. 2\$500) o metro, fazendo-nos entrega de uma cópia e do respectivo negativo. As novas cópias que, porventura, nos sejam necessárias nos serão fornecidas à razão de mil e quinhentos (Rs. 1\$500) o metro. Fica mais acordado que, sem um aviso prévio de trinta dias (30) de parte a parte, não poderá ser rescindido o presente acordo. (Fundo Família Ferrez - Júlio Ferrez)
} 
Abel, R. e R. Altman, (eds.). 2001. The Sounds of Early Cinema. Bloomington, IN: Indiana University Press.

Alencar, J. de. 1857. O Guarani. Romance Brasileiro. Rio de Janeiro: Empresa Nacional do Diário.

Araújo, V. de P. 1976. A Bela Época do Cinema Brasileiro. São Paulo: Perspectiva.

Aumont, J. e M. Marie, 2003. Dicionário teórico e crítico de cinema. São Paulo: Papirus.

Bernardet, J. C. 1979. Filmografia do cinema brasileiro (1900-1935). Jornal O Estado de S. Paulo. São Paulo: Governo do Estado de São Paulo, Secretaria da Cultura, Comissão de Cinema.

———. 2008. Historiografia clássica do cinema brasileiro. 2. ed. São Paulo: Annablume.

Biblioteca Nacional Digital Brasil. (Online: memoria.bn.br)

Brooks, P. 1976. The Melodramatic Imagination: Balzac, James, Melodrama and the Modes of Excess. New Haven: Yale University Press.

"Cinema Palace". 1908a. Gazeta de Notícias, Rio de Janeiro, 14 set., 6.

"Cinema-Palace”. 1908b. Jornal do Brasil, Rio de Janeiro, 20 set., 20. Cinemateca Brasileira: Banco de Dados. (Online: http://cinemateca.gov.br/)

“Circo Spinelli”. 1903. O Fluminense, Niterói, 20 ago., 3.

“Circo Spinelli”. 1904. Jornal do Brasil, Rio de Janeiro, 21 jun., 8.

"Circo Spinelli". 1906a. O Fluminense, Niterói, 20 mar., 3.

“Circo Spinelli”. 1906b. O Fluminense, Niterói, 23 mar., p. 3.

“Circo Spinelli”. 1906c. O fluminense, Niterói, 24 mar., 3

“Circo Spinelli”. 1906d. O Fluminense, Niterói, 5 mai., 2.

“Circo Spinelli”. 1906e. O Fluminense, Niterói, 5 mai., 4.

Costa, E. B. A. 2010. "Um estudo das comédias mágicas $O$ Chico e o Diabo e Os Irmãos Jogadores, de Benjamim de Oliveira". Repositório Institucional UFBA, 111-128, v. 13, n. 15. Disponível em:

https://repositorio.ufba.br/ri/handle/ri/2038. Acesso em 25 abr. 2017.

Carvalho, D. C. 2017. "O cinema silencioso e o som no Brasil (18941920)”. Galáxia (São Paulo, online), 85-97, n. 34. Disponível em:

https://revistas.pucsp.br/index.php/galaxia/article/view/28 088. Acesso em 10 jun. 2017. 
- - . 2014. Luz e sombra no écran: realidade, cinema e rua nas crônicas cariocas de 1894 a 1922, Campinas, Doutorado em Teoria e História Literária, Instituto de Estudos da Linguagem da Universidade de Campinas, 2014 (Online: http://repositorio.unicamp.br/jspui/handle/REPOSIP/26989 $\underline{0})$.

Candido, A. Formação da Literatura Brasileira: Momentos Decisivos (1750-1880). 2 Volumes. São Paulo, SP: Martins, 1959.

Dicionário Cravo Albin da Música Popular Brasileira. (Online: http://www.dicionariompb.com.br/)

Dimas, A. 1983. Tempos eufóricos (análise da revista Kosmos, 19041909). Ensaios 88. São Paulo: Editora Ática.

Faria, J. R. 1982. "José de Alencar: a polêmica em torno da adaptação teatral de O Guarani”. Letras. Curitiba. (31): 59-101.

Fullerton, J. 2001. "Sound, the jump cut, and 'trickality' in early Danish comedies. In The Sounds of Early Cinema, 87-94. Bloomington, IN: Indiana University Press.

Fundo Família Ferrez - Firma Marc Ferrez FF-FMF 2.0.1.3. Arquivo Nacional.

Fundo Família Ferrez - Júlio Ferrez: FF-JF: 2.0.2. Arquivo Nacional. Hemeroteca Digital Brasileira. (Online: http://memoria.bn.br/hdb/periodico.aspx)

IMDB: Internet Movie Database. (Online: http://www.imdb.com/)

Gunning, T. 1994. "The World as Object Lesson: Cinema Audiences, Visual Culture and the St. Louis World's Fair, 1904". Film History: Audiences and Fans Vol. 6, n. 4 (Winter): 422-444. Indiana University Press. (Online: https://kmanthorne.commons.gc.cuny.edu/files/2011/01/gu nningStLouis1904.pdf. Acesso em 31 mai. 2017.

Kiefer, B. 1977. História da música brasileira, dos primórdios ao início do séc. $X X$. Porto Alegre: Movimento.

Marks, M. M. 1997. Music and the Silent Film: contexts \& case studies (1895-1924). New York: Oxford University Press.

Mencarelli, F. A. 1999. Cena Aberta: A absolvição de um bilontra e o teatro de revista de Arthur Azevedo. Campinas: Editora da Unicamp.

La Mínima Circo e Teatro. Pagliacci. Disponível em http://www.laminima.com.br/site/agenda/pagliacci/. Acesso em: 13 jul. 2017.

Morettin, E. 1997. "A representação da história no cinema brasileiro (1907-1949)”. Anais do Museu Paulista, N. Sér. V. 5: 249-271. 
—- 2000. "Produção e formas de circulação do tema do Descobrimento do Brasil: uma análise de seu percurso e do filme Descobrimento do Brasil (1937), de Humberto Mauro". Rev. bras. Hist. São Paulo vol.20, n.39. (Online: http://www.scielo.br/scielo.php?pid=S010201882000000100006\&script=sci_arttext\&tlng=es). Acesso em: 11 jul. 2017.

. 2009. "Sonoridades do cinema dito silencioso: filmes cantantes, história e música”. Significação, v. 36, n. 31: 149162. Online:

http://www.revistas.usp.br/significacao/article/view/67094. Acesso em 25 mai. 2017.

. 2013. Humberto Mauro, cinema, história. São Paulo: Alameda.

Nasta, D. 2001. "Setting the Pace of a Heartbeat: The Use of Sound Elements in European Melodramas before 1915. In The Sounds of Early Cinema, p. 95-109. Bloomington, IN: Indiana University Press.

Neves, L. de O. 2006. As comédias de Artur Azevedo: em busca da história, Campinas. Doutorado em Teoria e História Literária, Instituto de Estudos da Linguagem da Universidade Estadual de Campinas (Online:

http://repositorio.unicamp.br/handle/REPOSIP/269841).

Oliveira, M. E. M. de A. R. 2005. "O indianismo alencariano e a narrativa da formação nacional." Graphos: Revista da PósGraduação em Letras - UFPB, João Pessoa, Vol. 7., N. 2/1: 135-139.

Pasta Benjamin de Oliveira: fotografias. Centro de Documentação e Informação da Fundação Nacional das Artes (CEDOCFUNARTE), Rio de Janeiro.

Schwarcz, L. M. 1993. O espetáculo das raças. Cientistas, instituições e questão racial no Brasil, 1870-1930. São Paulo: Cia das Letras.

Santos, L. A. dos. 2015. "O negro nos primórdios do cinema brasileiro: uma abordagem entre a literatura e a imprensa". Margens - Revista Interdisciplinar, vol. 9,n. 13: 130-141.

Scalvini, A. e C. de Ormeville. 1870. Il Guarany, melodramma in quattro atti. Musiche di Antonio Carlos Gomes. (Online: http://www.librettidopera.it/zpdf/guarany.pdf). Acesso em 31 mai. 2017.

Silva, E. 2007. Circo-teatro: Benjamim de Oliveira e a teatralidade circense no Brasil. São Paulo: Editora Altana.

Souza, J. I. de M. 2003. "O Rio civiliza-se”. In Imagens do passado: São Paulo e Rio de Janeiro nos primórdios do cinema, 105-161. São Paulo: Editora SENAC. 
Souza, S. C. M. de. 2002. "Simplesmente 'o Vasques', quando não 'o Chico”". As noites do Ginásio: teatro e tensões culturais na Corte (1832-1868). Campinas, Ed. da UNICAMP, 234-262.

Tabarin. 1622. Inventaire universel des oeuvres de Tabarin, contenant ses fantaisies, dialogues, paradoxes, gaillardises, rencontres, farces et conceptions. Paris: P. Rocollet et A. Estoc. (Online: http://gallica.bnf.fr/ark:/12148/btv1b86120488/f7.item.r=). Acesso em 4 abr. 2017.

“Teatro Apolo: Grande Companhia Lírica Italiana”. 1908. Jornal do Brasil, Rio de Janeiro, 20 set., 20.

"Teatro Lírico Fluminense - Companhia da Fênix Dramática: O Guarani”. 1874a. Jornal do Comércio, 3 mai., 6.

"Teatro Lírico Fluminense: Companhia da Phenix Dramática". 1874b. Jornal do Comércio, Rio de Janeiro, 28 mai., 6.

“Teatro São Pedro de Alcântara: Companhia Equestre Frank Brown”. 1908. Gazeta de Notícias, Rio de Janeiro, 14 set., 6.

Thomasseau, J. M. 2005. O melodrama. Tradução de Claudia Braga e Jacqueline Penjon. São Paulo: Perspectiva.

——_. 2009. Mélodramatiques. Vincennes, Presses Universitaires de Vincennes; Saint-Denis, Université Paris 8.

Usai, P. C. 2000. Silent Cinema: an introduction. New Preface by David Robinson, Preface to the first English Edition by Kevin Brownlow. London: Palgrave Macmillan/ BFI.

\section{FILMOGRAFIA}

A Canção do Aventureiro. [curta-metragem]. Produção: William Auler. Companhia Produtora: William e Cia. Brasil, 1908.

Dueto do Guarany. [curta-metragem]. Produção: William Auler. Companhia Produtora: William e Cia. Brasil, 1909.

Os Guaranis. [curta-metragem]. Produção: Labanca, Leal e Cia. Companhia Produtora: Photo-Cinematographia Brasileira. Brasil, 1968. Aprox. 12 min.

Terra em Transe. [longa metragem] Dir. Glauber Rocha. Mapa Films, Brasil, 1967. $111 \mathrm{~min}$. 